\title{
Effects of safflower oil supplementation in diet on growth performance and body fatty acid composition of turbot (Psetta maxima)
}

\author{
Mehmet Sukru Altundag • Serap Ustaoglu Tiril • Atilla Ozdemir
}

Received: 10 April 2013/Accepted: 6 August 2013/Published online: 17 August 2013

(C) The Author(s) 2013. This article is published with open access at Springerlink.com

\begin{abstract}
The aim of the study was to investigate the effects of the diets that contain safflower oil and fish oil as lipid sources, on growth, feed conversion and body composition in turbot (Psetta maxima). Two iso-nitrogenous and iso-lipidic diets (55\% protein and $14 \%$ lipid) were prepared that include $100 \%$ fish oil (FO group) and $100 \%$ safflower oil (SFO group) for turbots with average weight of $62.21 \pm 1.28 \mathrm{~g}$, and fish were fed with these diets for 104 days. At the end of the experiment, the weight gain, specific growth rate and feed conversion ratio were the highest in SFO group than in FO group $(p<0.05)$. Fatty acid composition of fish body reflected the fatty acid composition determined in the experimental diets. The amounts of palmitic acid (PA; C16:0), oleic acid (OA; C18:1n-9), linoleic acid (LA; C18:2n-6) and docosahexaenoic acid (DHA; C22:6n-3) were dominant fatty acids in fish body. It was confirmed that the usage of safflower oil instead of fish oil in turbot feed did not generate any negative effects on growth, feed conversion and the values regarding the growth performance.
\end{abstract}

Keywords Turbot $\cdot$ Psetta maxima $\cdot$ Safflower oil $\cdot$ Growth $\cdot$ Body composition

\section{Introduction}

One of the basic dietary ingredients containing high energy in fish feeds for carnivorous marine fish is fish oil, because of its high digestibility and sufficient content of essential fatty acids (EFA), in particular long-chain polyunsaturated fatty acids (PUFA) (Nasopoulou and Zabetakis 2012). The supply of fish oil is limited and their cost is continuously increasing,

M. S. Altundag · S. U. Tiril ( ()

Department of Aquaculture, Faculty of Fisheries, University of Sinop, Sinop, Turkey e-mail: serapt@sinop.edu.tr

A. Ozdemir

Ministry of Food, Agriculture and Livestock, General Directorate of Fisheries and Aquaculture, Ankara, Turkey 
affecting feeding costs and consequently total production costs in aquaculture. For this reason, many researches have been carried out in order to evaluate the alternative lipid sources as potential substitutes in fish diets (Tacon and Jackson 1985; Richard et al. 2006).

In order to reduce dependence on fish oil, significant advances have occurred over the past few years in replacing of fish oil with plant oils. By substituting feeds with plant oils, it also serves to reduce costs due to the fact that vegetable oil sources have continuously increasing production and better economic value. Several studies are carried out to investigate certain vegetable oils as possible sustainable partial or total substitutes for fish oil in fish feeds. The most common vegetable oils used for fish feeds are soybean, linseed, rapeseed, sunflower, palm and olive oil. Soybean and rapeseed oil are considered most possible alternative lipid sources for fresh water and marine fish since they are rich in PUFAs, especially linoleic acid (18:2n-6), but devoid of n-3 PUFA (Mourente et al. 2005).

The essential fatty acid requirement of fish varies between species qualitatively and quantitatively. In contrast to freshwater species, juvenile and sub-adult marine fish species cannot be met the EFA requirements by $\mathrm{C} 18$ PUFA and are required the $\mathrm{n}-3$ highly unsaturated fatty acids (HUFA), eicosapentaenoic acid (EPA) and docosahexaenoic acid (DHA). For juveniles of several marine species including turbot, red sea bream and European sea bass, the EFA requirements can be met by levels of n-3 HUFA of less than or up to $1 \%$ of the dry weight of the diet (Tocher 2010). Otherwise, partially or totally substitution of fish oil by vegetable oils, e.g., olive oil, soybean oil or canola oil, was investigated for these species (Alkistis and Alexis 2001; Martins et al. 2006; Huang et al. 2007). Alkistis and Alexis (2001) informed that the growth parameters and fish body composition were not significantly affected by the use of olive oil, soybean oil and fish oil singly or in combination in diets for sea bass. Huang et al. (2007) also not found any adverse effect by the partially or totally use of canola oil in feeds for red sea bream.

In the present study, the nutritive value of safflower oil for turbot (Psetta maxima) was evaluated and the effects of safflower oil on growth performance, feed conversion, body and fatty acid composition of turbot were investigated.

\section{Materials and methods}

Fish and maintenance

The study was conducted at the Central Fisheries Research Institute (CFRI), Trabzon, Turkey, in a seawater recirculation system. The experimental fish were obtained from the same research institute. Experimental fish (avg $62 \mathrm{~g}$ ) were fasted for a day; weighed; and randomly stocked in six rectangle fiberglass tanks (water volume of 500-1; $1 \times 1.15 \times 0.5 \mathrm{~m}$ ) at 50 fish per tank. Water inflow was adjusted to $5 \mathrm{l} / \mathrm{min}$, and supplemental aeration was provided via airstone diffusers. The natural seawater from the Blacksea (salinity was about $18 \mathrm{gL}^{-1}$ ) was used in the experiment. Temperature was measured twice in a day $\left(18.35 \pm 2.9^{\circ} \mathrm{C}\right)$, and dissolved oxygen $\left(8.00 \pm 0.1 \mathrm{mgL}^{-1}\right)$ and $\mathrm{pH}(7.76 \pm 0.13)$ were measured once a day. At the beginning of the experiment, 10 fish from the stock tank and at the end of the experiment 8 fish from each tank were sampled and analyzed for muscle tissue composition. At the end of the trial, all fish were individually weighed to assess the growth performances.

\section{Experimental diets}

Diet ingredients were obtained from a local fish feed manufacturer (Sibal Inc., Sinop, Turkey). Safflower oil was obtained from a commercial feed firm (Gülce Yağ/Kurtuluş 
Yağ San.Tic.A.Ş., Manisa, Turkey). Two experimental diets of equivalent protein (55\%) and lipid (14\%) contents were prepared containing $100 \%$ fish oil or $100 \%$ safflower oil (Table 1 ). Both feeds contained approximately $4 \%$ fish oil from the fish meal. Therefore, the $100 \%$ safflower oil group also contained $4 \%$ fish oil from the fish meal. The ingredients were thoroughly mixed, homogenized, moistened by the addition of $40 \%$ water and pelleted $(3.0 \mathrm{~mm})$ in a mincer. The pellets were dried at $70{ }^{\circ} \mathrm{C}$ for $12 \mathrm{~h}$ and in room temperature for $5 \mathrm{~h}$ and then cut into pieces approximately $5 \mathrm{~mm}$ in length. All feeds were stored at $-40{ }^{\circ} \mathrm{C}$ in plastic bags until need for feeding.

Feeding

The experiment was conducted in triplicate in randomly assigned tanks. During experimental period, fish were fed diets by hand to apparent satiation twice a day (at 09:00 and 16:00), 6 days a week. The feeding procedure was done carefully in order to be sure all fish took the feed. The experiment lasted 104 days.

\section{Chemical analysis}

Chemical composition of wet samples of fish and diets were analyzed by standard methods (AOAC 1995). Samples were dried to a constant weight at $105^{\circ} \mathrm{C}$ to determine moisture level. Crude protein was determined by measuring nitrogen (Nx6.25) using the Kjeldahl method. Crude lipid was extracted with petroleum ether by the Soxhlet method, and the ash was determined by incineration at $550{ }^{\circ} \mathrm{C}$ in a muffle furnace. All analyses were performed in triplicate.

Table 1 Formulation and proximate compositions of the FO and SFO diets

* Per kg feed: 12,500 IU vitamin A; 2,500 IU vitamin D3; $10 \mathrm{mg}$ vitamin $\mathrm{K} 3$; $10 \mathrm{mg}$ vitamin $\mathrm{B} 1$; $20 \mathrm{mg}$ vitamin $\mathrm{B} 2 ; 15 \mathrm{mg}$ vitamin B6; $0.03 \mathrm{mg}$ vitamin B12; $250 \mathrm{mg}$ vitamin C; $200 \mathrm{mg}$ niacin; $1 \mathrm{mg}$ biotin; $10 \mathrm{mg}$ folic acid; $60 \mathrm{mg}$ pantothenic acid; $1,000 \mathrm{mg} \mathrm{Ca} ; 130 \mathrm{mg}$ ethoxyquin; $600 \mathrm{mg}$ magnesium; $450 \mathrm{mg}$ potassium; $90 \mathrm{mg}$ zinc; $12 \mathrm{mg}$ manganese; $5 \mathrm{mg} \mathrm{Cu}$

${ }^{\text {a }} \mathrm{NFE}+$ Crude fiber $=100-$ $(\%$ protein $+\%$ lipid $+\%$ ash $)$

\begin{tabular}{|c|c|c|}
\hline & \multicolumn{2}{|c|}{ Experimental diets } \\
\hline & FO & SFO \\
\hline \multicolumn{3}{|l|}{ Ingredients $\left(\mathrm{g} \mathrm{kg}^{-1}\right)$} \\
\hline Fish meal & 600 & 600 \\
\hline Extracted soybean meal & 115 & 115 \\
\hline Corn protein & 101.5 & 101.5 \\
\hline Wheat flour & 80 & 80 \\
\hline Fish oil & 100 & - \\
\hline Safflower oil & - & 100 \\
\hline Vitamin premix $(*)$ & 2 & 2 \\
\hline Mineral premix $(*)$ & 1.5 & 1.5 \\
\hline \multicolumn{3}{|c|}{ Proximate composition (\%) } \\
\hline Moisture & 9.72 & 5.84 \\
\hline Protein & 54.21 & 55.88 \\
\hline Lipid & 14.45 & 13.48 \\
\hline Ash & 7.67 & 7.24 \\
\hline $\mathrm{NFE}+$ Crude fiber ${ }^{\mathrm{a}}$ & 23.67 & 23.40 \\
\hline Gross energy $\mathrm{kJg}^{-1}$ & 20.8 & 20.6 \\
\hline
\end{tabular}




\section{Fatty acid analysis}

Lipid extraction of the fish and diet samples was performed according to the method of Bligh and Dyer (1959), using chloroform/methanol (2:1,v/v). Methyl esters were prepared by transmethylation using $2 \mathrm{M}$ potassium hydroxide in methanol and $\mathrm{n}$-hexane according to the method described by Ichihara et al. (1996), and extracted oil sample was dissolved in $2 \mathrm{ml}$ hexane, followed by $4 \mathrm{ml}$ of $2 \mathrm{M}$ methanolic $\mathrm{KOH}$. After centrifugation at 4,000 rpm and at $4{ }^{\circ} \mathrm{C}$ for $10 \mathrm{~min}$, the upper phase was taking in a separate tube and covered with parafilm. A total of $1 \mathrm{ml}$ from samples was taken and injected into the GC. Fatty acid peaks were identified from standard fatty acid mixtures, and the percent of individual fatty acids was calculated.

Statistical analysis

All statistical analyses were performed using the program Statistica 7.0 for Windows. To assess normality of distributions, Kolmogorov-Smirnov test was used, and homogeneity of variances was tested using the Levene's $F$ test. One-way ANOVA was applied, followed by Tukey's test to locate any differences among treatments. A significance level of $5 \%$ was used in all tests.

\section{Results}

Diet proximate and fatty acid composition

All test diets contained similar concentrations of the proximate constituents (Table 1). The diet of SFO group was characterized by having increased proportions of 18:1n-9, and reduced proportions of saturated fatty acids (SFA), monounsaturated (MUFA; 24:1) and n-3 PUFA (22:6n-3) compared to diet of FO group (Table 2). However, linolenic acid (18:3n-3, LNA) and eicosapentaenoic acid (EPA, 20:5n-3), in the SFO diet, were the highest $(p<0.05)$. The FO diet had the highest concentrations of palmitoleic acid $(16: 1$, POA), linoleic acid (18:2n-6c: LA) and docosahexaenoic acid (22:6n-3, DHA) with values of $6.03,18.89$ and $20.34 \%$ lipid, respectively. The $n-3 / n-6$ ratio was 1.49 and $1.50 \%$ for the FO and SFO diets, respectively.

\section{Growth performance and feed conversion}

The experimental diets were well accepted by the fish, and no pathological signs were observed during the study. The survival rate was $100 \%$. Diet treatment affected the growth performance of the turbot and weight gain (WG), and specific growth rate (SGR) and feed conversion ratio (FCR) were significantly affected by diets (Table 3 ). The weight gain $(62.34 \mathrm{~g})$ and SGR $(0.65 \%)$ of SFO group were higher than in FO group (52.23 g; $0.58 \%$, respectively) $(p<0.05)$. In point of final condition factor, there was significant difference between FO and SFO groups $(p<0.05)$. Feed conversion was significantly more efficient in SFO group (0.90) than in FO group (1.07) $(p<0.05)$.

Proximate composition of muscle tissue

At the end of the experiment, protein, lipid and ash contents of muscle tissue were statistically different between groups (Table 4) $(p<0.05)$. The protein, lipid and ash contents of SFO group were higher than those of FO group. 
Table 2 Fatty acid composition of the experimental diets (\% of total fatty acids)

\begin{tabular}{|c|c|c|}
\hline \multirow[t]{2}{*}{ Fatty acids } & \multicolumn{2}{|l|}{ Groups } \\
\hline & FO & SFO \\
\hline C14:0 & $4.45 \pm 0.02^{\mathrm{a}}$ & $1.33 \pm 0.09^{b}$ \\
\hline C16:0 & $18.87 \pm 0.11^{\mathrm{a}}$ & $10.49 \pm 0.26^{\mathrm{b}}$ \\
\hline C18:0 & $3.63 \pm 0.01^{\mathrm{a}}$ & $2.86 \pm 0.09^{b}$ \\
\hline C20:0 & $0.28 \pm 0.00^{\mathrm{a}}$ & $0.28 \pm 0.01^{\mathrm{a}}$ \\
\hline$\Sigma$ SFA & $27.23 \pm 0.15^{\mathrm{a}}$ & $14.96 \pm 0.43^{b}$ \\
\hline C16:1 & $6.03 \pm 0.31^{\mathrm{a}}$ & $1.83 \pm 0.18^{\mathrm{b}}$ \\
\hline C18:1 n-9 & $18.26 \pm 0.04^{\mathrm{a}}$ & $24.18 \pm 0.37^{b}$ \\
\hline C20:1 & $1.41 \pm 0.01^{\mathrm{a}}$ & $1.40 \pm 0.01^{\mathrm{a}}$ \\
\hline C24:1 & $0.53 \pm 0.06^{\mathrm{a}}$ & $0.14 \pm 0.01^{\mathrm{b}}$ \\
\hline$\Sigma$ MUFA & $26.23 \pm 0.32^{\mathrm{a}}$ & $27.55 \pm 0.21^{b}$ \\
\hline $\mathrm{C} 18: 3 \mathrm{n}-3$ & $1.23 \pm 0.00^{\mathrm{a}}$ & $1.49 \pm 0.00^{\mathrm{b}}$ \\
\hline C20:5 n-3 & $9.16 \pm 0.02^{\mathrm{a}}$ & $9.20 \pm 0.02^{\mathrm{b}}$ \\
\hline $\mathrm{C} 22: 6 \mathrm{n}-3$ & $20.34 \pm 0.15^{\mathrm{a}}$ & $17.21 \pm 0.55^{\mathrm{b}}$ \\
\hline$\Sigma$ n-3 PUFA & $30.73 \pm 0.18^{\mathrm{a}}$ & $27.89 \pm 0.56^{\mathrm{b}}$ \\
\hline DHA/EPA & 2.22 & 1.87 \\
\hline C18:2 n-6c & $18.89 \pm 0.00^{\mathrm{a}}$ & $17.62 \pm 0.17^{\mathrm{b}}$ \\
\hline C18:2 n-6t & $0.28 \pm 0.00^{\mathrm{a}}$ & $0.29 \pm 0.02^{\mathrm{a}}$ \\
\hline C20:3 n-6r & $0.28 \pm 0.01^{\mathrm{a}}$ & $0.26 \pm 0.01^{\mathrm{b}}$ \\
\hline C18:3 n-6 & $0.17 \pm 0.00^{\mathrm{a}}$ & $0.12 \pm 0.00^{\mathrm{b}}$ \\
\hline C20:4 n-6 & $0.87 \pm 0.01^{\mathrm{a}}$ & $0.26 \pm 0.00^{\mathrm{b}}$ \\
\hline$\Sigma$ n-6 PUFA & $20.49 \pm 0.00^{\mathrm{a}}$ & $18.55 \pm 0.19^{b}$ \\
\hline$\sum \mathrm{n} 3 / \mathrm{n} 6$ & 1.49 & 1.50 \\
\hline
\end{tabular}

Fatty acid composition of muscle tissue

Muscle fatty acid compositions of turbot were significantly influenced by dietary lipid source. The SFO group was quite low SFA, MUFA and n-6 PUFA, but there was no difference between groups in terms of n-3 PUFA. Fish fed with SFO diet showed increased proportions of n-3 PUFA in combination with reduced amounts of 18:1n-9 and 18:2n-6, except for 18:3n-3, as compared with fish fed with FO diet (Table 5). The greatest concentration of DHA was identified in the FO group, but did not differ from SFO group $(p>0.05)$, whereas the greatest concentration of EPA was determined in the SFO group $(p<0.05)$. The $\mathrm{n}-3 / \mathrm{n}-6$ ratio observed as $1.20,0.99$ and $1.09 \%$ for the groups, respectively.

\section{Discussion}

The replacement of fish oil by some vegetable oils in marine fish diets has been studied in turbot (Regost et al. 2003), gilthead sea bream (Caballero et al. 2002; Izquierdo et al. 2005) and sea bass (Izquierdo et al. 2003) without negative effect on growth performances of fish. The results of this study have shown that it is possible to substitute up to $100 \%$ fish oil by safflower oil in diets for turbot without negative effect on growth performance and feed utilization, confirming the similar results found in some experiments with vegetable oils 
Table 3 Growth performance and feed efficiency in fish fed the experimental diets

\begin{tabular}{lrr}
\hline & \multicolumn{1}{l}{ FO } & \multicolumn{1}{c}{ SFO } \\
\hline Initial body weight $(\mathrm{g})$ & $62.28 \pm 1.36^{\mathrm{a}}$ & $62.13 \pm 1.20^{\mathrm{a}}$ \\
Final body weight $(\mathrm{g})$ & $114.51 \pm 3.23^{\mathrm{a}}$ & $124.47 \pm 3.28^{\mathrm{b}}$ \\
Weight gain $(\mathrm{g})_{\mathrm{FCR}^{1}}$ & $52.23^{\mathrm{a}}$ & $62.34^{\mathrm{b}}$ \\
$\left.\mathrm{SGR}^{\mathrm{a}} \%\right)^{2}$ & $1.07 \pm 0.03^{\mathrm{a}}$ & $0.90 \pm 0.02^{\mathrm{b}}$ \\
Initial condition factor $^{\mathrm{b}}$ & $0.58 \pm 0.03^{\mathrm{a}}$ & $0.65 \pm 0.04^{\mathrm{b}}$ \\
Final condition factor & $1.45 \pm 0.02^{\mathrm{a}}$ & $1.47 \pm 0.01^{\mathrm{b}}$ \\
\hline
\end{tabular}

Values are mean $\pm \operatorname{SEM}(n=3)$

Values within the same row with different superscripts denote significant differences $(p<0.05)$

${ }^{1}$ Feed conversion ratio $(\mathrm{FCR})=$ total feed intake/total weight gain

${ }^{2}$ Specific growth rate $(\mathrm{SGR})=[(\ln$ final weight $-\ln$ initial weight $) /$ days $] \times 100$

Table 4 Proximate composition (\% wet weight) of muscle tissue in fish fed the experimental diets

\begin{tabular}{lrrr}
\hline Proximate composition & \multicolumn{1}{l}{ Initial } & \multicolumn{1}{l}{ FO } & \multicolumn{1}{l}{ SFO } \\
\hline Moisture (\%) & $79.19 \pm 0.02$ & $78.48 \pm 0.48^{\mathrm{a}}$ & $77.55 \pm 0.26^{\mathrm{a}}$ \\
Protein (\%) & $17.50 \pm 0.50$ & $17.56 \pm 0.66^{\mathrm{a}}$ & $17.96 \pm 0.33^{\mathrm{b}}$ \\
Lipid (\%) & $1.78 \pm 0.04$ & $1.80 \pm 0.09^{\mathrm{a}}$ & $1.92 \pm 0.04^{\mathrm{b}}$ \\
Ash (\%) & $1.67 \pm 0.14$ & $1.59 \pm 0.19^{\mathrm{a}}$ & $1.88 \pm 0.15^{\mathrm{b}}$ \\
\hline
\end{tabular}

Values are mean $\pm \operatorname{SEM}(n=3)$

Values within the same row with different superscripts denote significant differences $(p<0.05)$

(canola oil, soybean oil, linseed oil; rapeseed oil, palm oil) in different fish species (brook charr, turbot, Atlantic salmon and European Sea Bass) (Guillou et al. 1995; Regost et al. 2003, Menoyo et al. 2005; Richard et al. 2006). Bell et al. (1994) and Regost et al. (2003) reported no negative effect on growth of turbot fed diets contained safflower oil and linseed oil. Bell et al. (1994) investigated three diets containing fish oil, safflower oil and linseed oil for juvenile turbot (1.2 g). No differences in final weight were found, and any pathological lesions were evident during the trial. Regost et al. (2003) also searched three diets containing fish oil, soybean oil and linseed oil for marketable size turbot (579 g). It was reported that the growth of turbot was high, but the incorporation of vegetable oils in the diets resulted in a slight decrease in growth as compared to those fed with fish oil-based diet. In the present study, no adverse effect on growth performance of turbot fed diet contained safflower oil. On the contrary, the weight gain and SGR of SFO group were higher than in FO group. FCR was not negatively affected by using SFO in feed. Our data showed that it is possible to replace fish oil by safflower oil in diets for turbot. The results denoted the higher ability of turbot to accept vegetable oils in comparison with other marine fish species such as gilthead seabream (Sparus aurata) (Izquierdo et al. 2005). In addition, previous studies have shown that the use of vegetable oils instead of fish oil in turbot diets depends on the n-3 content of the basal diet (Bell et al. 1994, 1999).

Little effect of dietary lipid source was observed in tissue composition of turbot, as reported for other fish species (rainbow trout, Atlantic salmon) (Greene and Selivonchick 1990; Dosanjh et al. 1998). In the present study, the crude protein, lipid and ash of fish tissue fed the SFO diet were significantly higher than those fed the FO diet. Though, the 
Table 5 Fatty acid composition of muscle tissue in fish fed the experimental diets (\% of total fatty acids)
Values are mean $\pm \operatorname{SEM}(n=3)$

Values within the same row with different superscripts denote significant differences $(p<0.05)$

\begin{tabular}{|c|c|c|c|}
\hline \multirow[t]{2}{*}{ Fatty acids } & \multicolumn{3}{|l|}{ Groups } \\
\hline & Initial & FO & SFO \\
\hline C14:0 & $4.55 \pm 0.16$ & $3.77 \pm 0.26^{\mathrm{a}}$ & $1.54 \pm 0.12^{b}$ \\
\hline C16:0 & $13.50 \pm 0.23$ & $15.56 \pm 0.38^{\mathrm{a}}$ & $12.00 \pm 0.15^{\mathrm{b}}$ \\
\hline C18:0 & $2.37 \pm 0.19$ & $2.47 \pm 0.16^{\mathrm{a}}$ & $2.47 \pm 0.16^{\mathrm{a}}$ \\
\hline C20:0 & $0.25 \pm 0.03$ & $0.31 \pm 0.02^{\mathrm{a}}$ & $0.30 \pm 0.07^{a}$ \\
\hline$\Sigma$ SFA & $20.67 \pm 0.12$ & $22.11 \pm 0.53^{\mathrm{a}}$ & $16.31 \pm 0.24^{\mathrm{b}}$ \\
\hline C16:1 & $6.07 \pm 0.17$ & $3.30 \pm 0.23^{\mathrm{a}}$ & $1.75 \pm 0.08^{b}$ \\
\hline C18:1 n-9 & $18.22 \pm 0.58$ & $16.21 \pm 0.30^{\mathrm{a}}$ & $14.77 \pm 0.55^{\mathrm{b}}$ \\
\hline C20:1 & $1.90 \pm 0.04$ & $1.77 \pm 0.04^{\mathrm{a}}$ & $1.67 \pm 0.07^{\mathrm{b}}$ \\
\hline $\mathrm{C} 24: 1$ & $0.23 \pm 0.03$ & $0.36 \pm 0.03^{\mathrm{a}}$ & $0.12 \pm 0.01^{b}$ \\
\hline$\Sigma$ MUFA & $26.42 \pm 0.74$ & $21.64 \pm 0.29^{\mathrm{a}}$ & $18.31 \pm 0.48^{b}$ \\
\hline C18:3 n-3 & $1.38 \pm 0.04$ & $1.20 \pm 0.07^{\mathrm{a}}$ & $1.40 \pm 0.09^{a}$ \\
\hline C20:5 n-3 & $3.25 \pm 0.14$ & $2.22 \pm 0.07^{\mathrm{a}}$ & $2.65 \pm 0.16^{b}$ \\
\hline$C 22: 6 n-3$ & $17.60 \pm 0.76$ & $17.63 \pm 0.58^{\mathrm{a}}$ & $17.31 \pm 0.51^{\mathrm{a}}$ \\
\hline$\Sigma \mathrm{n}-3$ PUFA & $22.23 \pm 0.60$ & $21.05 \pm 0.56^{\mathrm{a}}$ & $21.36 \pm 0.21^{\mathrm{a}}$ \\
\hline DHA/EPA & 5.41 & 7.94 & 6.53 \\
\hline C18:2 n-6c & $15.67 \pm 0.55$ & $19.12 \pm 0.28^{\mathrm{a}}$ & $16.83 \pm 0.37^{\mathrm{t}}$ \\
\hline C18:2 n-6t & $1.15 \pm 0.03$ & $1.49 \pm 0.10^{\mathrm{a}}$ & $1.89 \pm 0.05^{\mathrm{b}}$ \\
\hline C20:3 n-6r & $0.26 \pm 0.01$ & $0.25 \pm 0.01^{\mathrm{a}}$ & $0.23 \pm 0.01^{\mathrm{a}}$ \\
\hline C18:3 n-6 & $0.20 \pm 0.01$ & $0.18 \pm 0.00^{\mathrm{a}}$ & $0.23 \pm 0.01^{b}$ \\
\hline C20:4 n-6 & $1.23 \pm 0.00$ & $0.20 \pm 0.02^{\mathrm{a}}$ & $0.45 \pm 0.08^{b}$ \\
\hline$\Sigma$ n-6 PUFA & $18.51 \pm 0.52$ & $21.24 \pm 0.35^{\mathrm{a}}$ & $19.63 \pm 0.35^{b}$ \\
\hline$\sum \mathrm{n} 3 / \mathrm{n} 6$ & 1.20 & 0.99 & 1.09 \\
\hline
\end{tabular}

lipid content of turbot was low (between 1.80 and $1.92 \%$ ), confirming earlier reports (Sérot et al. 1998).

Tocher (2010) stated, in contrast to freshwater species the studies on juvenile and subadult marine fish, that the EFA requirements cannot be met by C18 PUFA and that the n- 3 PUFA, EPA and DHA are required. For juveniles of several species including turbot, red sea bream, European sea bass, red drum and Korean rockfish, the EFA requirements can be met by levels of n-3 HUFA of less than or up to $1 \%$ of the dry weight of the diet (Tocher 2010). The ARA requirement was estimated a value of around $0.3 \%$ of the dry weight of the diet in juvenile turbot (Castell et al. 1994; Bell et al. 1995). Additionally, optimum DHA/EPA ratios have been defined in diets for turbot larvae around 2 (Reitan et al. 1994). In the present study, ARA and DHA/EPA ratios were determined for FO and SFO groups between 0.87 and 0.26 and $2.22-1.87$, respectively.

Although the ARA and DHA/EPA ratios were high in diet of FO group, the growth was better in SFO group.

In terms of the muscle fatty acid compositions of groups fed experimental diets, the SFO group has higher fatty acid composition than the FO group. Namely, in the SFO group, $\Sigma$ SFA, oleic acid (8:1n-9), linoleic acid (18:2n-6), $\Sigma$ MUFA and $\Sigma$ n-6 PUFA ratios were low, but linolenic acid (18:3n-3), EPA, ARA and $\Sigma$ n-3 PUFA ratios were high.

There were significant differences between groups $(p<0.05)$. Bell and Dick (1990) and Sargent et al. (1999) reported that DHA and EPA are the major PUFAs of cell membranes in fish and 20:4n-6 has an important physiological function in the membrane of fish since it 
is known to be the main precursor fatty acid of eicosanoid. Castell et al. (1994) suggested also that dietary 20:4n-6 is essential for juvenile turbot.

Results of this study suggest that potential exists for replacing fish oil with safflower oil in the feeds of turbot without negative effects in growth performance and fatty acid composition in muscle tissue. Further studies are needed to determine the effects of mixture utilization of several oil sources and safflower oil on flesh quality and muscle fatty acid composition of turbot in long-term studies.

Acknowledgments This paper is Mehmet Sükrü Altundag's Master thesis. We extend our gratefulness to Central Fisheries Research Institute for providing us the fish and to all friends for their help.

Open Access This article is distributed under the terms of the Creative Commons Attribution License which permits any use, distribution, and reproduction in any medium, provided the original author(s) and the source are credited.

\section{References}

Alkistis CRP, Alexis MN (2001) Effects of different dietary oils in sea bass (Dicentrarchus labrax) nutrition. Aquac Int 9:463-476

AOAC (1995) Official methods of analysis, 16th edn. Association of Official Analytical Chemists, Arlington, VA

Bell MV, Dick JR (1990) Molecular species composition of phosphatidylinositol from brain, retina, liver and muscle of cod (Gadus morhua). Lipids 25:691-694

Bell JG, Tocher DR, MacDonald FM, Sargent JR (1994) Effects of diets rich in linoleic (18:2n-6) and alinonenic (18:3n-3) acids on growth, lipid class and fatty acid compositions and eicosanoid production in juvenile turbot (Scophthalmus maximus L.). Fish Physiol Biochem 13:105-118

Bell JG, Castell JD, Tocher DR, MacDonald FM, Sargent JR (1995) Effects of different dietary arachidonic acid:docosahexaenoic acid ratios on phospholipid fatty acid compositions and prostaglandin production in juvenile turbot (Scophthalmus maximus). Fish Physiol Biochem 14:139-151

Bell JG, Tocher DR, Farndale BM, McVicar AH, Sargent JR (1999) Effects of essential fatty acid deficient diets on growth, mortality, tissue histopathology and fatty acid compositions in juvenile turbot (Scophthalmus maximus). Fish Physiol Biochem 20:263-277

Bligh E, Dyer W (1959) A rapid method of total lipid extraction and purification. Can J Physiol Pharmacol 37:911-917

Caballero MJ, Obach G, Rosenlund G, Montero D, Gisvold M, Izquierdo MS (2002) Impact of different dietary lipid sources on growth, lipid digestibility, tissue fatty acid composition and histology of rainbow trout, Oncorhynchus mykiss. Aquaculture 214:253-271

Castell JD, Bell JG, Tocher DR, Sargent JR (1994) Effects of purified diets containing different combinations of arachidonic and docosahexaenoic acid on survival, growth and fatty acid composition of juvenile turbot (Scophthalmus maximus). Aquaculture 128:315-333

Dosanjh BS, Higgs DA, McKenzie DJ, Randall DJ, Eales JG, Rowshandeli N, Rowshandeli M, Deacon G (1998) Influence of dietary blends of menhaden oil and canola oil on growth, muscle lipid composition and thyroidal status of Atlantic salmon (Salmo salar) in sea water. Fish Physiol Biochem 19:123-134

Greene DHS, Selivonchick DP (1990) Effects of dietary vegetable, animal and marine lipids on muscle lipid and hematology of rainbow trout (Oncorhynchus mykiss). Aquaculture 89:165-182

Guillou A, Soucy P, Khalil M, Adambounou L (1995) Effects of dietary vegetable and marine lipid on growth, muscle fatty acid composition and organoleptic quality of flesh of brook charr (Salvelinus fontinalis). Aquaculture 136:351-362

Huang SSY, Oo AN, Higgs DA, Brauner CJ, Satoh S (2007) Effect of dietary canola oil level on the growth performance and fatty acid composition of juvenile red sea bream, Pagrus major. Aquaculture 271:420-431

Ichihara K, Shibahara A, Yamamoto K, Nakayama T (1996) An improved method for rapid analysis of the fatty acids of glycerolipids. Lipids 31:535-539

Izquierdo MS, Obach G, Arantzamendi L, Montero D, Robaina L, Rosenlund G (2003) Dietary lipid sources for seabream and seabass: growth performance, tissue composition and flesh quality. Aquac Nutr 9:397-407 
Izquierdo MS, Montero D, Robaina L, Caballero MJ, Rosenlund G, Ginés R (2005) Alterations in fillet fatty acid profile and flesh quality in gilthead seabream (Sparus aurata) fed vegetable oils for a long term period. Recovery of fatty acid profiles by fish oil feeding. Aquaculture 250:431-444

Martins D, Gomes E, Rema P, Dias J, Ozório ROA, Valente LMP (2006) Growth, digestibility and nutrient utilization of rainbow trout (Oncorhynchus mykiss) and European sea bass (Dicentrarchus labrax) juveniles fed different dietary soybean oil levels. Aquac Int 14(3):285-295

Menoyo D, López-Bote CJ, Obach A, Bautista JM (2005) Effect of dietary fish oil substitution with linseed oil on the performance, tissue fatty acid profile, metabolism, and oxidative stability of Atlantic salmon. J Anim Sci 83:2853-2862

Mourente G, Good JE, Bell JG (2005) Partial substitution of fish oil with rapeseed, linseed and olive oils in diets for European sea bass (Dicentrarchus labrax L.): effects on flesh fatty acid composition, plasma prostaglandins E2 and F2a, immune function and effectiveness of a fish oil finishing diet. Aquac Nutr $11: 25-40$

Nasopoulou C, Zabetakis I (2012) Benefits of fish oil replacement by plant originated oils in compounded fish feeds. A review. LWT-Food Sci Technol 47:217-224

Regost C, Arzel J, Cardinal M, Robin J, Laroche M, Kaushik SJ (2001) Dietary lipid level, hepatic lipogenesis, and flesh quality in turbot (Psetta maxima). Aquaculture 193:291-309

Regost C, Arzel J, Robin J, Roselund G, Kaushik J (2003) Total replacement of fish oil by soybean oil with return to fish oil in turbot (Psetta maxima): I. Growth performance, flesh fatty acid profile, and lipid metabolism. Aquaculture 217:465-482

Reitan KI, Rainuzzo JR, Olsen Y (1994) Influence of lipid composition of live feed on growth, survival and pigmentation of turbot larvae. Aquac Int 2:33-48

Richard N, Mourente G, Kaushik S, Corraze G (2006) Replacement of a large portion of fish oil by vegetable oils does not affect lipogenesis, lipid transport and tissue lipid uptake in European seabass (Dicentrarchus labrax L.). Aquaculture 261:1077-1087

Sargent J, Bell G, McEvoy L, Tocher D, Estevez A (1999) Recent developments in the essential fatty acid nutrition of fish. Aquaculture 177:191-199

Sérot T, Gandemer G, Demaimay M (1998) Lipid and fatty acid compositions of muscle from farmed and wild adult turbot. Aquac Int 6:331-343

Tacon AGJ, Jackson AJ (1985) Utilization of conventional and unconventional protein sources in practical fish feeds. In: Cowey CB, Mackie A, Bell J (eds) Nutrition and feeding in fish. Academic Press, London, pp 119-145

Tocher DR (2010) Fatty acid requirements in ontogeny of marine and freshwater fish. Aquac Res 41:717-732 